\title{
Socio-Economic Factors and Effects of Low Female Enrolments in Electrical Trade in Adamawa State
}

\author{
Joseph Zambwa ${ }^{1}$, Aniekan Elijah Asukwo ${ }^{1}$, Grace James ${ }^{1 *}$ \\ ${ }^{1}$ Modibbo Adama University of Technology, Yola Adamawa State, 2076, NIGERIA \\ *Corresponding Author \\ DOI: https://doi.org/10.30880/ojtp.2021.06.01.008 \\ Received 08 October 2020; Accepted 25 January 2021; Available online 31 March 2021
}

\begin{abstract}
This study determined the perceived socio-economic factors and effects of low enrolment of female students in Electrical Installation and Maintenance Works Trade in Government Technical Colleges on women empowerment in Adamawa State. Two specific objectives guided the present study. The population of the study consisted of 13 Electrical Installation and Maintenance Work Trade (EIMWT) teachers and 129 parents (either father or mother) of National Technical Certificate Two (NTCII) EIMWT students in three Government Technical Colleges of Adamawa State. The research subjects of the study comprised the entire population, thus no sampling was done. The instrument was validated by three experts and yielded a reliability co-efficient of 0.81 . Mean was used in data analysis to answer the research questions. The findings of the study revealed an increasing number of technically unskilled female folks in Adamawa State as major perceived socio-economic effect. Other findings include gender inequality and regress in the fight to end poverty among the female folk in Adamawa State. The study recommended among others that Adamawa State Government in collaboration with corporate bodies should embark on an awareness campaign in order to enlighten parents and family members on the prospects of EIMWT especially to female gender.
\end{abstract}

Keywords: Socio-economic factors, socio-economic effects, low enrolment, electrical trade, women employment

\section{Introduction}

The participation of females in TVET (especially technical education programmes) in Nigeria institutions is generally low and very poor when compared to enrolment in general education programmes (Aina, 2006; Adelakun, Oviawe, and Garba, 2015). Okolocha (2006) noted that since the introduction of TVET into the Nigerian educational system, enrolment in TVET programmes in Nigeria has remained low. This poor enrolment is further accentuated in female enrolment in TVET (Ezeliora and Ezeokana, 2010). This is supported by Agwi and Puyate (2017) whose study revealed that the poor enrolment into TVET programmes in Nigeria is more disturbing on female gender's participation. This low enrolment of females in TVET programmes have been attributed to several factors. According to Wubon (2013), education has not necessarily been a priority for the female gender because of socio-cultural beliefs and backward mindsets. It is generally believed that a girl should get married and stay at her husband's house without pursuing career dream. On the contrary, a male is considered to be superior to the female-child in many aspects especially in education, and that is why in most cases, only the male child has access to education. Similarly, Dokubo and Deebom (2017) hinged the poor enrolment of females on poverty, preference of male child, cultural and religious beliefs. Ayonmike (2014) noted that the government, schools, the society, and parents had a role to play in the poor enrolment of the female students in TVET programmes. Nevertheless, the socio-economic effect of low female enrolment in TVET has not yet been fully investigated. 
Socio-economic factors can be viewed as the interaction between the social and economic habits of a group of people which comprises the factors of a social and economic nature (occupation, income, etc), and indicates a person's status within a community (Lutz, 2009). Socioeconomic factors link financial and social issues together, and also include governmental factors (Ayonmike, 2014). A study by Ngelu, Omwenga, Mungatu, and Iravo (2018) reveals that enrolling a girl into both primary school and secondary school is more likely to improve the quality of life for the household as compared to without schooling. Based on this finding, therefore, it is plausible to infer that enrolling the female students into Electrical Installation and Maintenance Works Trade (EIMWT) as a programme offered at the secondary school level in technical colleges in Adamawa State is more likely to improve the quality of life for Adamawa State households. On the other hand, failing to send female students to school will be diminishing the quality of life for Adamawa State households. Similarly, a study by Dokubo and Deebom (2017) identified some of the effect of female low participation in technical education programmes to include increase in crime, increase in prostitution, and females becoming corporate beggars as its effect. This implies that female low enrolment in technical education reduces women level of productivity in the labour market. This is line with Okafor and Arinze (2012) who stressed that women's education will increase the level of women in the labour workforce of the nation and also increases productivity and self-employment in the informal sector.

\subsection{Statement of Problem}

TVET is viewed as a field of education that empowers the beneficiary with the necessary skills, knowledge, and attitude for self-employment. Sadly, the high level of unemployment and poverty among female population in Adamawa is very alarming. This should be a major concern to the stakeholders. The unemployment and poverty can be caused by many factors which include socio-economic, socio-cultural, and family background. The objective of TVET is to prepare and train students to acquire the requisite trade skills that would enable them secure employment, become self-employed and be able to employ others, or pursue further education in tertiary institutions. Women can also benefit from this; however, students' enrolment records of the three Government Technical Colleges spread across the three educational zones of Adamawa State shows that there is a decline in the enrolment of female students into Electrical Installation and Maintenance Works Trade (Adamawa State Post-Primary Board, 2019). In 2016/2017 session, out of 70 students that were enrolled, $88.57 \%$ (62 students) were males and 11.43\% (8 students) were females. In 2017/2018 session, there was an increase in enrolment as 146 students were enrolled; sadly, 94.52\% (138 students) were males, leaving just 5.48\% (8 students) as females. A decrease in enrolment was observed in the 2018/2019 session as 129 students were enrolled; sadly, only $4.65 \%$ (6 students) were females and 95.35\% (123 students) were males. The enrolment records therefore reveal that female students' enrolment into Electrical Installation and Maintenance Works Trade in the technical colleges in Adamawa State is low and discouraging. This has raised questions like what could be the cause of this undesired outcome. Could some perceived socio-economic factors be responsible for the low enrolment? What perceived effects have this low female enrolment had on women empowerment in Adamawa State? Additionally, if this trend in female students' enrolment is not addressed urgently, the Electrical Installation and Maintenance Works Trade of the technical colleges in Adamawa State might end up having no female students enrolled in the programme in the near future, thus leaving the Adamawa community with the dearth of female technicians in electrical installations and maintenance. It is against this background that this study sought to ascertain the perceived socio-economic factors affecting female enrolment in Electrical Installation and Maintenance Works Trade in the technical colleges in Adamawa and the effects that this low enrolment has on women empowerment.

\subsection{Objectives of Study}

Specifically, the study sought to:

i. determine the perceived socio-economic factors affecting the enrolment of female students in Electrical Installation and Maintenance Works Trade in Government Technical Colleges in Adamawa State.

ii. determine the perceived socio-economic effects of low enrolment of female students in Electrical Installation and Maintenance Works Trade in Government Technical Colleges on women empowerment in Adamawa State.

\section{Literature Review}

Ayonmike (2014) revealed that socio-economic factors which include governmental factors affect female participation in technical education programme. The author listed the factors as: Cost-sharing in education; introduction of structural adjustment policies; introduction of higher user charges or fees increased educational costs to families in terms of higher school fees payment; policy related factors (lack of goals and adequate monitoring of gender equality); poor provision of infrastructural facilities such as library, classroom blocks, workshops, laboratories and recreational facilities; poor provision of consumable materials such as wood nails, wires, rods, glues etc for student's practicals; poor provision of qualified technical education lecturers; and poor funding of technical education; gender biased TVET curriculum materials. This is corroborated by Dokubo and Deebom (2017) who lists poverty as one of the causes affecting 
female's enrolment into technical education programmes. This is also in line with Olugbile (2010) who observed that gender gap in education in Nigeria could be as a result of economic costs.

Afu, Gbobo, Ukofia and Itakure (2017) reports that socio-economic factors, which includes family poverty and direct cost of schooling, affects female enrolment into technical education. Other factors include government lukewarm attitude towards technical and vocational education (TVE), the perception of the society towards technical and vocational education, and lack of candidate's interest. According to Ediagbonya, Agbaje and Suberu (2012), the inadequacies of facilities/infrastructural materials, qualified teachers and career counsellors have equally not helped out in boosting participation of female in technical and vocational programmes. A study by Adelakun, Oviawe, and Barfa (2015) indicated some factors affecting the implementation of a female-enhanced Technical Vocational Education and Training (TVET) in Nigeria. Some of the factors listed include socio-economic factors like lack of incentives to encourage the students, discriminatory labour market practices, poor scholarship scheme for TVET students, among others.

West (2007) emphasized that together with the fundamental socio-cultural bias in favour of males, the economic factor, especially in terms of grinding poverty and hunger, is also probably the most influential in adversely affecting female participation in education. In such harsh economic circumstances, both direct and hidden costs to a family of sending daughters to school are perceived by parents to be prohibitive in terms of the provision of books, paper and uniforms/clothing (important for social reasons) as well as the loss of vital help at home and on the land.

Female enrolment into EIMWT will have the effect of reducing poverty, aiding socio-economic growth and thus contribute in empowering the females in Adamawa State. This is corroborated by Hodge (2017) who asserts that investing in the education of females brings high returns in terms of breaking cycles of poverty and aiding economic growth, and also improves children's and women's survival rates and health, delays child marriage and early pregnancies, empowers women both in the home and the workplace, and helps tackle climate change.

\section{Methodology}

The study adopted a descriptive survey research design. The researchers selected a sample of respondents and administered questionnaires to them. The instrument used for collecting data for this study was a structured questionnaire developed by the researchers titled Socio-economic Factors and Effects of Low Female Enrolment Questionnaire (SFELFEQ). The questionnaire was divided into two sub-sections based on the two research questions that guided the study. The responses on the questionnaire were structured on 5-point Likert scale of Strongly Agree (SA) = 5, Agree (A) $=4$, Undecided $(\mathrm{U})=3$, Disagree $(\mathrm{D})=2$ and Strongly Disagree $(\mathrm{SD})=1$. The questionnaire was validated by three experts from Department of Electrical Technology Education, Modibbo Adama University of Technology, Yola, Adamawa State. The population for the study consisted of 142 respondents (13 teachers and 129 parents of NTCII students in EIMWT). There was no sampling because the small and manageable population. Cronbach alpha formular was used to determine the reliability was found to be 0.81 , hence the instrument adjudged to be highly reliable. A total of 142 copies of the structured questionnaire were responded to and $100 \%$ returned. The data collected were analysed and presented in tables. Mean and Standard Deviation were used in data analysis to answered the research questions. The data collected for this study was analysed using Statistical Package for Social Sciences (SPSS) version 20.0. In answering the Research Questions, an item with a mean of 3.50 and above was considered as Agreed (A) while an item with a mean less than 3.50 (3.49 and below) was considered as Disagreed (D).

\section{Results}

\subsection{Objective 1}

The first research question is presented as follows:

What are the perceived socio-economic factors affecting the enrolment of female students in Electrical Installation and Maintenance Works Trade in Government Technical Colleges in Adamawa State?

Table 1 shows the respondents (teachers and parents) agreed on six out of 10 perceived socio-economic factors affecting female enrolment in Electrical Installation and Maintenance Works Trade in Government Technical Colleges in Adamawa State. Furthermore, the table shows that lack of commitment by the government and stakeholders to a female-enhanced Electrical Installation and Maintenance Works Trade and absence of government programmes and policies that keep females in school are the major perceived socio-economic factors affecting female enrolment in Electrical Installation and Maintenance Works Trade in Government Technical Colleges in Adamawa State. 
Table 1 - Responses of teac hers and parents on the perceived socio-economic factors affecting the enrolment of female students

\begin{tabular}{|c|c|c|c|c|c|c|c|c|}
\hline \multirow[t]{2}{*}{$\mathbf{S} / \mathbf{N}$} & \multirow[t]{2}{*}{ Items } & \multicolumn{6}{|c|}{$\begin{array}{c}\text { Respondents } \\
\mathrm{n}_{\mathrm{T}}=13, \mathrm{n}_{\mathrm{P}}=129, \mathrm{n}_{\mathrm{G}}=142\end{array}$} & \multirow[t]{2}{*}{ Remarks } \\
\hline & & $\bar{x}_{T}$ & $\sigma_{T}$ & $\bar{x}_{P}$ & $\sigma_{P}$ & $\bar{x}_{G}$ & $\sigma_{G}$ & \\
\hline i. & $\begin{array}{l}\text { Absence of scholarship to female } \\
\text { enrolees in Electrical Installation and } \\
\text { Maintenance Works Trade }\end{array}$ & 3.38 & 1.19 & 3.57 & 1.40 & 3.55 & 1.38 & Agreed \\
\hline i. & $\begin{array}{l}\text { Increased educational costs of } \\
\text { Electrical } \\
\text { Maintenance } \\
\begin{array}{l}\text { Installation } \\
\text { families }\end{array}\end{array}$ & 3.46 & 1.12 & 3.26 & 1.30 & 3.28 & 1.29 & Disagreed \\
\hline i. & $\begin{array}{l}\text { Lack of commitment by government } \\
\text { and stakeholders to a female- } \\
\text { enhanced Electrical Installation and } \\
\text { Maintenance Works Trade }\end{array}$ & 3.69 & 1.03 & 3.82 & 1.14 & 3.81 & 1.13 & Agreed \\
\hline v. & $\begin{array}{l}\text { Absence of financial aids/grants to } \\
\text { female enrolees in Electrical } \\
\text { Installation and Maintenance Works } \\
\text { Trade to carry out projects for } \\
\text { exhibition }\end{array}$ & 4.00 & 0.70 & 3.49 & 1.34 & 3.54 & 1.30 & Agreed \\
\hline v. & $\begin{array}{l}\text { High cost of raw materials for } \\
\text { practical project in Electrical } \\
\text { Installation and Maintenance Works } \\
\text { Trade }\end{array}$ & 3.76 & 0.83 & 3.48 & 1.59 & 3.50 & 1.53 & Agreed \\
\hline i. & $\begin{array}{l}\text { Absence of government programmes } \\
\text { and policies that keep females in } \\
\text { school }\end{array}$ & 4.07 & 0.75 & 3.76 & 1.25 & 3.79 & 1.22 & Agreed \\
\hline i. & Parents' level of income & 3.38 & 1.32 & 3.34 & 1.37 & 3.35 & 1.36 & Disagreed \\
\hline i. & Large family structure & 2.92 & 0.95 & 3.15 & 1.38 & 3.13 & 1.35 & Disagreed \\
\hline к. & $\begin{array}{l}\text { Poor retention of female gender in } \\
\text { technical careers like Electrical } \\
\text { Installation and Maintenance Works }\end{array}$ & 3.07 & 1.44 & 3.41 & 1.46 & 3.38 & 1.45 & Disagreed \\
\hline к. & Parents level of education & 3.46 & 1.50 & 3.62 & 1.32 & 3.61 & 1.33 & Agreed \\
\hline & Grand Mean & 3.51 & & 3.49 & & 3.49 & & Disagreed \\
\hline
\end{tabular}

$\bar{x}_{T}=$ Mean responses of Teachers, $\bar{x}_{p}=$ Mean responses of Parents, $\sigma_{T}=$ Standard Deviation of Teachers, $\sigma_{P}=$ Standard Deviation of Parents, $\bar{x}_{G}=$ Item mean of means, $\sigma_{G}=$ Item Standard Deviation of means.

Based on the results presented in Table 1, the mean score of items ranges from 3.50 to 3.81. Given a grand mean of 3.49 , the respondents disagreed on the perceived socio-economic factors affecting female enrolment in Electrical Installation and Maintenance Works Trade in Government Technical Colleges in Adamawa State. Furthermore, with item standard deviation of means ranging from 1.13 to 1.53 , the results indicate that there is little dispersion in the opinions of the respondents.

\subsection{Objective 2}

The second research question is presented as follows:

What are the perceived socio-economic effects of low enrolment of female students in Electrical Installation and Maintenance Works Trade in Government Technical Colleges on women empowerment in Adamawa State?

Table 2 shows the respondents (teachers and parents) agreed on seven out of 10 perceived socio-economic effects of low enrolment of female students in Electrical Installation and Maintenance Works Trade in Government Technical Colleges on women empowerment in Adamawa State. Furthermore, the tables shows that the increasing number of technically unskilled female folks in Adamawa State and regress in the fight to end poverty among the female folk in Adamawa State are the major perceived socio-economic effects of low enrolment of female students in Electrical Installation and Maintenance Works Trade in Government Technical Colleges on women empowerment in Adamawa State. 
Table 2 - Responses of teachers and parents on the perceived socio-economic effects of low enrolment of female students

\begin{tabular}{|c|c|c|c|c|c|c|c|c|}
\hline \multirow[t]{2}{*}{$\mathbf{S} / \mathbf{N}$} & \multirow[t]{2}{*}{ Items } & \multicolumn{6}{|c|}{$\begin{array}{c}\text { Respondents } \\
\mathrm{n}_{\mathrm{T}}=13, \mathrm{n}_{\mathrm{P}}=129, \mathrm{n}_{\mathrm{G}}=142\end{array}$} & \multirow[t]{2}{*}{ Remarks } \\
\hline & & $\overline{\boldsymbol{x}}_{T}$ & $\sigma_{T}$ & $\bar{x}_{P}$ & $\sigma_{P}$ & $\overline{\boldsymbol{x}}_{G}$ & $\sigma_{G}$ & \\
\hline i. & $\begin{array}{l}\text { Inability for the female gender to } \\
\text { contribute to strengthening }\end{array}$ & 2.92 & 0.95 & 3.00 & 1.36 & 2.99 & 1.33 & Disagreed \\
\hline & Adamawa State's economy & & & & & & & \\
\hline i. & $\begin{array}{l}\text { Increased level of crime among the } \\
\text { female gender in Adamawa State }\end{array}$ & 2.46 & 1.05 & 2.68 & 1.26 & 2.66 & 1.24 & Disagreed \\
\hline i. & $\begin{array}{l}\text { Increased level of illiteracy among } \\
\text { the female gender in Adamawa State }\end{array}$ & 2.69 & 0.85 & 3.09 & 1.44 & 3.05 & 1.40 & Disagreed \\
\hline v. & $\begin{array}{l}\text { It has contributed to the reduced } \\
\text { number of females in the technical } \\
\text { skills labour market in Adamawa } \\
\text { State }\end{array}$ & 3.46 & 1.12 & 3.69 & 1.42 & 3.67 & 1.39 & Agreed \\
\hline v. & $\begin{array}{l}\text { Regress in the fight to end poverty } \\
\text { among the female folk in Adamawa } \\
\text { State }\end{array}$ & 3.53 & 0.87 & 3.82 & 1.02 & 3.80 & 1.01 & Agreed \\
\hline i. & $\begin{array}{l}\text { It has played a role in gender } \\
\text { inequality in Adamawa State }\end{array}$ & 3.07 & 0.95 & 3.86 & 1.31 & 3.78 & 1.30 & Agreed \\
\hline i. & $\begin{array}{l}\text { It has contributed to the dearth of } \\
\text { female instructors in Electrical } \\
\text { Installation and Maintenance Works } \\
\text { Trade in Adamawa State }\end{array}$ & 3.23 & 1.09 & 3.67 & 1.30 & 3.63 & 1.28 & Agreed \\
\hline i. & $\begin{array}{l}\text { It has contributed to a less conducive } \\
\text { environment for would-be practicing } \\
\text { female technicians in Electrical } \\
\text { Installation and Maintenance Works } \\
\text { Trade }\end{array}$ & 3.00 & 1.15 & 3.87 & 1.23 & 3.79 & 1.24 & Agreed \\
\hline к. & $\begin{array}{l}\text { It has contributed to the decline in } \\
\text { the earning power and capabilities of } \\
\text { the female gender in Adamawa State }\end{array}$ & 3.38 & 0.96 & 3.56 & 1.12 & 3.54 & 1.10 & Agreed \\
\hline к. & Increasing number of technically & 3.69 & 1.03 & 3.99 & 0.96 & 3.96 & 0.97 & Agreed \\
\hline
\end{tabular}
unskilled female folks in Adamawa State

\section{Grand Mean}

$\bar{x}_{T}=$ Mean responses of Teachers, $\bar{x}_{p}=$ Mean responses of Parents, $\sigma_{T}=$ Standard Deviation of Teachers, $\sigma_{P}=$ Standard Deviation of Parents, $\bar{x}_{G}=$ Item mean of means, $\sigma_{G}=$ Item Standard Deviation of means.

Based on the results presented in Table 2, the mean score of items ranges from 3.54 to 3.96. Given a grand mean of 3.48 , the respondents disagreed on the perceived socio-economic effects of low enrolment of female students in Electrical Installation and Maintenance Works Trade in Government Technical Colleges on women empowerment in Adamawa State. Furthermore, with standard deviation ranging from 0.97 to 1.40 , the results indicate that there is little dispersion in the opinions of the respondents.

\section{Discussion}

\subsection{The Perceived Socio-Economic Factors Affecting The Enrolment of Female Students}

Findings with respect to research question one shows that the respondents (teachers and parents) agreed on six out 10 perceived socio-economic factors affecting female enrolment in Electrical Installation and Maintenance Works Trade in Government Technical Colleges in Adamawa State which are: Absence of scholarship to female enrolees in Electrical Installation and Maintenance Works Trade, Lack of commitment by government and stakeholders to a female-enhanced Electrical Installation and Maintenance Works Trade, Absence of financial aids/grants to female enrolees in Electrical Installation and Maintenance Works Trade to carry out projects for exhibition, High cost of raw materials for practical project in Electrical Installation and Maintenance Works Trade, Absence of government programmes and policies that keep females in school, Parents level of education. This finding was collaborated by Ayonmike (2014), and Adelakun, Oviawe, and Barfa (2015), who found out that factors bordering on parents level of education and policy-related issues like financial aids/grants affects female enrolment. Furthermore, respondents did not consider increased educational costs 
of Electrical Installation and Maintenance Works Trade to families, parents' level of income, large family structure, and poor retention of female gender in technical careers like Electrical Installation and Maintenance Works as perceived socio-economic factors affecting female enrolments. This is in contrast to Olugbile (2010), Dokubo and Deebom (2017), and Afu, Gbobo, Ukofia and Itakure (2017), who all established that poverty and cost-related factors affect female enrolments.

\subsection{Socio-Economic Effects of Low Enrolment of Female Students}

Findings with respect to research question two shows that the respondents (teachers and parents) agreed on seven out of 10 perceived socio-economic effects of low enrolment of female students in Electrical Installation and Maintenance Works Trade in Government Technical Colleges on women empowerment in Adamawa State which are: It has contributed to the reduced number of females in the technical skills labour market in Adamawa State, Regress in the fight to end poverty among the female folk in Adamawa State, It has played a role in gender inequality in Adamawa State, It has contributed to the dearth of female instructors in Electrical Installation and Maintenance Works, It has contributed to a less conducive environment for would-be practicing female technicians in Electrical Installation and Maintenance Works Trade, It has contributed to the decline in the earning power and capabilities of the female gender in Adamawa State, and Increasing number of technically unskilled female folks in Adamawa State. This finding is line with Okafor and Arinze (2012) who stressed that women's education will increase the level of women in the labour workforce of the nation and also increase productivity and self-employment in the informal sector. Furthermore, the respondents did not consider inability for the female gender to contribute to strengthening Adamawa State's economy, increased level of crime among the female gender in Adamawa State, and increased level of illiteracy among the female gender in Adamawa State as perceived socio-economic effects of low enrolment of female students. This finding is distinct from the study by Dokubo and Deebom (2017) which revealed some of the effects of female low participation in technical education programmes to include increase in crime, increase in prostitution, and females becoming corporate beggars.

\section{Conclusion}

The findings of this study have revealed that there is a lack of commitment by the government and stakeholders towards encouraging a female-enhanced Electrical Installation and Maintenance Works Trade. Additionally, the absence of government programmes and policies that would help keep females in school also constitutes the socio-economic factors affecting female enrolment. Furthermore, the low enrolment of females into the trade has contributed to the increasing number of technically unskilled female folks in Adamawa State, thus also leading to a regress in the fight to end poverty among the female folk in Adamawa State. Therefore, if women empowerment is to be sustained, mechanisms should be put in place to improve female enrolment into EIMWT as a way of investing in the education of females in view of high returns in terms of breaking cycles of poverty and social vices that the females might be lured into, and thus aiding economic growth.

\section{Recommendations}

In view of the findings of the study, the following recommendations are made:

i. The Adamawa state government should establish a sustainable financing scheme for the female trainees of EIMWT as a show of commitment to a female-enhanced Electrical Installation and Maintenance Works Trade, in order to encourage more female enrolments into the programme.

ii. Provisions and favourable policies should be made by the Adamawa State Government to encourage and increase the number of technically skilled female folks in EIMWT in Adamawa State.

\section{Acknowledgement}

We thank all individuals who participated in this research especially in the process of instrument development, data collection, and analysis.

\section{References}

Adamawa State Post-Primary Board (2019). Demographic Information on Electrical Installation and Works Trade in Technical Colleges of Adamawa State. Yola: Technical Education Directorate

Adelakun, O. A., Oviawe, J. I., \& Garba, G. I. (2015). Strategies for Enhancing Female Participation in Technical, Vocational Educcation and Training (TVET) in Nigeria. Advances in Social Sciences Research Journal, 2(4), 11-20

Afu, M. O., Gbobo, V. F., Ukofia, I. F., \& Itakure, Z. S. (2017). Effect of Gender Imbalance in The Enrolment of Students in Public Secondary Schools in Gwagwalada Area Council, Federal Capital Territory, Abuja, Nigeria. International Journal of Scientific Research in Education, 10(2): 201-211 
Agwi, V. I. A. \& Puyate, S. T. (2017). Strategies for improving female students enrolment in technical vocational education and training (TVET) programmes in Rivers and Bayelsa States. Journal of Education in Development Areas, $25(1), 65-80$

Aina, O. (2006). Education Trust Fund Sanitization Workshop: Technical and Vocational Education (TVE) in Nigeria: the way Forward. Ilorin: Apex Press Nigeria Ltd

Ayonmike, C. S. (2014). Factors Affecting Female Participation in Technical Education Programme: A Study of Delta State University, Abraka. Journal of Education and Human Development, 3(3): 227-240

Dokubo, N. I. \& Deebom, M. T. (2017). Gender disparity towards students enrollment in technical education in rivers state: causes, effects and strategies. International Journal of Research - Granthaalayah, 5(10): 1-10

Ediagbonya, K., Agbaje, M. \& Suberu, A. K. (2012). Analysis of factors influencing business education students' enrollment pattern in N.C.E. programme in Federal college of education, Okene Kogi State. WEEIS International Journal of Arts and Combined Sciences, 3(1): 38 - 49

Ezeliora, B. \& Ezeokana, J. O. (2010). Inhibiting influences of some traditional practices in the home on girl-child's scientific development. International Journal of FAWE Nigeria, 2(1): 31-42

Hodge, S. (2017). Six ways in which educating girls benefit wider their community, Retrieved from https://thecircle.ngo/six-positive-impacts-educating-girls

Lutz, M. A. (2009). Social economics. In: J. Peil \& I. V. Staveren (ed.), Handbook of Economics and Ethics. Massachussets: Edward Elgar Publishing

Ngelu, J. M., Omwenga, J., Mungatu, J., \& Iravo, M. (2018). Effect of gender empowerment programmes on improving quality of life in Kenya: Evidence from Machakos County. Microeconomics and Macroeconomics, 6(1), 9-19

Okafor, V. E. \& Arinze, F. O. (2012). Gender Accessibility and Equality in Education: The Implication to Manpower Development in Nigeria. African Research Review, 6(3): 284-290

Okolocha, C. C. (2006). Vocational technical education in Nigeria: Challenges and the wayforward. Unizik Orient Journal of Education, 2(1), 180-119

Olugbile S. (2010). Varsity Enrolment: Females Improve in Male-dominated Courses. Punch Newspaper. Section A; 2010. p. 2

Statistical Package for Social Sciences (2011). IBM Statistical Package for Social Sciences: User's Guide. Version 20.0 for windows. IBM Corp., Armonk, NY

United Nations Development Programme (2019). Goal 4: Quality education. https://www.undp.org/content/undp/en/home/sustainable-development-goals/goal-4-quality-education.html (Retrieved on 5th August 2019)

United Nations Educational, Scientific and Cultural Organization (2016). Recommendation concerning Technical and Vocational Education and Training (TVET). https://unesdoc.unesco.org/ark:/48223/pf0000245068. page $=5$ (Retrieved on 6th August 2019)

West, M. S. (2007). Unprecedented urgency: Gender discrimination in faculty hiring at The University of California. NWSA Journal, 19(3): 199-211

Wubon, A. (2013). Girl-Child Education: Important for National Development. Daily Independent, Nigeria Newspaper (Retrieved 20 $0^{\text {th }}$ May 2014) 